\title{
Effect of Soybean (Glycine max) Seed Inoculation with Liquid and Carrier Based Rhizobium cultures and Phosphorus Levels on Productivity and Physico-Chemical Properties of Soil
}

\author{
Shish Ram Jakhar ${ }^{1}$, Vinod Kumar ${ }^{1}$, N. G. Mitra ${ }^{1}$ and Ompal Singh ${ }^{2 *}$ \\ ${ }^{1}$ Department of Soil Science and Agricultural Chemistry, J.N. Krishi Vishwa Vidyalaya, \\ Jabalpur - 482004 (M.P.), India \\ ${ }^{2}$ Department of Plant Physiology, J.N. Krishi Vishwa Vidyalaya, Jabalpur - 482004 \\ (M.P.), India \\ *Corresponding author
}

\begin{tabular}{|l|}
\hline Ke y w o r d s \\
$\begin{array}{l}\text { Soybean, carrier and } \\
\text { liquid-based } \\
\text { Rhizobium cultures, } \\
\text { nodulation and yield }\end{array}$ \\
\hline Article Info \\
\hline $\begin{array}{l}\text { Accepted: } \\
\text { 18 May 2018 } \\
\text { Available Online: } \\
\text { 10 June 2018 }\end{array}$ \\
\hline
\end{tabular}

\section{Introduction}

Soybean (Glycine max), is an important legume crop in the world in terms of total production and international trade (Simmond et al., 1999). Soybean contains about $20 \%$ oil on dry matter basis with $30-50 \%$ of protein (Kwarteng and Towler, 1994). It also has

\section{A B S T R A C T}

A field experiment was conducted at JNKVV, Jabalpur during kharif 2015, to evaluate the effect of Rhizobium cultures with supplementation of inorganic phosphorus $(\mathrm{Pi})$ onthe performance of soybean and physico-chemical properties of soil in a Vertisol soil. The experiment was laid out in Randomized Block Design with three replications comprised of 12 treatments including two type soybean rhizobial cultures (liquid formulation and carrier based) in combination with three levels of Pi (@ 40, 80 and $120 \mathrm{~kg} \mathrm{P}_{2} \mathrm{O}_{5} \mathrm{ha}^{-1}$ ) and one control (unfertilized + uninoculated). The result reveled that the nodulation higher at 45 days after sowing (DAS) and followed by a reduction at maturity. Treatment $\mathrm{P}_{80}+\mathrm{LRh}(80$ $\mathrm{kg} \mathrm{P}_{2} \mathrm{O}_{5}+$ liquid inoculum of Rhizobium) for enhanced the nodulation attributes, over the control at 45 DAS. The treatment $\mathrm{P}_{80}+\mathrm{LRh}$ gave maximum nodules number $(81.1 \%)$, weight $(89.1 \%$ fresh and $78.5 \%$ dry) and $\mathrm{N}$ content $(64.4 \%)$ over control (6.9 number/plant, $103 \mathrm{mg} /$ plant, $65 \mathrm{mg} / \mathrm{plant}$ and $2.03 \%$ ), respectively. Similar treatment increased available $\mathrm{N}$ andPin soil at harvest by 42.8 and $92.8 \%$, respectively over control (189 and $14 \mathrm{~kg} / \mathrm{ha}$, respectively) and statistically no difference was notice in case of $\mathrm{K}$ and it was maximum by $\mathrm{P}_{80}+\mathrm{LRh}(295 \mathrm{~kg} / \mathrm{ha})$. The treatment $\mathrm{P}_{80}+\mathrm{LRh}$ also increased seed and stover yields of soybeanby 75.4 and $88.8 \%$ over the control (1025 and $2206 \mathrm{~kg} / \mathrm{ha}$ ), respectively. While the treatment $\mathrm{P}_{120}+\mathrm{LRh}$ exhibited numerically higher values of $\mathrm{P}_{80}+\mathrm{LRh}$ but statistically at par to $\mathrm{P}_{80}+\mathrm{LRh}$. 
as $300 \mathrm{~kg}$ of $\mathrm{N} \mathrm{ha}^{-1}$ in addition to the release in the soil of $20-30 \mathrm{~kg} \mathrm{~N} \mathrm{ha}^{-1}$ for the following crop had been estimated (Hungria et al., 2006). To improve soybean yield, biological $\mathrm{N}_{2}$ fixation, contribution to soil fertility restoration, inoculation with efficient strains of Bradyrhizobia has already been tested in several countries (Tairo and Ndakidemi, 2014).

Phosphorus supplementation can enhance plant growth by increasing the efficiency of biological $\mathrm{N}_{2}$ fixation, enhancing the availability of other macronutrients in legumes (Makoi et al., 2013). Hence, it can be attributed to have a positive interaction between Rhizobia inoculation and $\mathrm{P}$ supply (Tairo and Ndakidemi, 2014). There were several reports on the interaction between Rhizobia inoculation and $\mathrm{P}$ supply. Akpalu et al., (2014) had reported that combination of beneficial bacteria of soil and phosphorus in legume plants significantly increased nodulation, pod formation and development, and a subsequent grain yield comparatively to the single use of phosphorus or beneficial bacteria.

The inoculation with Rhizobium and phosphorus supplementation improved the macronutrient uptake ( $\mathrm{N}$, Pand $\mathrm{K}$ ) in different organs of the whole plant of soybean (Tairo and Ndakidemi, 2014). Highly effective and competitive Rhizobium strains and a supply of appropriate amount of phosphorus (Scherer et al., 2008) could markedly increase legume growth and $\mathrm{N}$ fixation.

Phosphorus (P) and $\mathrm{N}$ play specific role in symbiotic $\mathrm{N}_{2}$-fixation through their effects on nodulation and $\mathrm{N}_{2}$-fixation process ( $\mathrm{O}$ ' Hara et al., 2002). $\mathrm{N}_{2}$-fixation is very sensitive to $\mathrm{P}$ deficiency due to reduce nodule mass and decreased ureide production. Symbiotic Nfixation has a high $\mathrm{P}$ demand because the process consumes large amounts of energy and energy generating metabolism strongly depends upon the availability of $\mathrm{P}$ (Plaxton, 2004).

\section{Materials and Methods}

A field experiment was conducted at research field of the Department of Soil Science \& Agricultural Chemistry, JNKVV, on soybean and were inoculated with both the types of Rhizobium inoculants (liquid formulation and carrier based), the isolate $\mathrm{R}_{33}$ wereobtained from the project AINP on Soil Biodiversity \& Biofertilizers (ICAR), JNKVV, Jabalpur. All the technical efforts were endeavored to maintain the soybean-rhizobial population to up the standard $10^{8}$ to $10^{-9} \mathrm{cfug}^{-1}$ or ml for both liquid and carrier inoculants. The liquid inoculant was directly used for the experiment, whereas for carrier based inoculants lignite was used. The recommended dose of fertilizer $\mathrm{N}: \mathrm{P}_{2} \mathrm{O}_{5}: \mathrm{K}_{2} \mathrm{O}$ was applied @ 20:80:20 kg ha ${ }^{-1}$ for soybean crop in the form of urea, single super phosphate (SSP) and muriate of potash (MOP). Urea and MOP were supplemented as basal applications to each plot as per recommendation and SSP was applied as per scheduled dose of treatments.

\section{Seed Inoculation and Sowing}

Soybean seeds in polythene bags were slightly moistened and then treated with carbendazim fungicide@ $2 \mathrm{~g} \mathrm{~kg}^{-1}$ seed. Seeds were allowed to air dry under shade. Then the seeds were inoculated individually with the bioinoculant Rhizobium liquid and carrier based cultures at double the recommended dose $20 \mathrm{ml}$ or $\mathrm{g} \mathrm{kg}^{-1}$ of seed, respectively using sterilized gum acacia $(2 \%)$ as adhesive. The field experiment was carried out at research farm JNKVV Jabalpur during kharif season of 2015.The seeds were sown in the respective plot @ 60 $\mathrm{kg} \mathrm{ha}^{-1}$. Recommended package of practices was followed to maintain plant population, protection and growth. 


\section{Nodulation}

From each replication were carrying out nodulation with three plants per plot. Nodulation studies were done at 21 and 45 DAS by irrigating the plots and uprooting plants carefully taking care to avoid any losses or damage of nodules. The rhizosphere soil was washed in the running tap water. After proper washing, nodules per plant were counted manually. After counting, the nodules were detached from the roots and its fresh weight was recorded in number of nodules/plant. These nodules were kept in small paper bags

The nodules were oven dried in hot air oven at $60{ }^{0} \mathrm{C}$ for 3-4 days (till constant weight) to record their oven dried weight (mg/plant).The estimation of nitrogen in nodules was performed as done with the plant samples. Contents of $\mathrm{N}$ in nodule were analyzed on dry weight basis as per standard procedures (Amma, 1989).

\section{Soil Properties}

The surface $(0-15 \mathrm{~cm})$ soil samples were collected from the experimental site before sowing of soybean crop and after harvest. The soil samples were air dried and crushed with wooden pestle and mortar and sieved through $2 \mathrm{~mm}$ sieve. The material passed through the sieve was used for determination of various characters. Soil $\mathrm{pH}$ was determined in 1:2.5 soils-water suspensions (Piper, 1950) using Systronics $\mathrm{pH}$ meter. Determination of organic carbon was done by Walkley and Black's rapid titration method (1934) as described by Piper (1950).A suitable quantity of the soil was digested with chromic acid and sulphuric acid making the use of heat of dilution of sulphuric acid. Excess of chromic acid left over unreduced by the organic matter of the soil was determined by a titration with Ferrous Ammonium Sulphate solution using diphenylamine indicator. Available $\mathrm{N}$ in soil was determined by using alkaline permanganate method (Subbiah and Asija, 1956). A known weight of soil is mixed with excess of alkaline permanganate and distilled. The phosphorus content of soil was estimated by extraction procedure as described by Olsen et al., (1954). Soil available phosphorus was extracted using $0.5 \mathrm{M} \mathrm{NaHCO}_{3}(\mathrm{pH} 8.5)$ and determination was done by ascorbic acid method as described by Miller and Keeney (1982). The available potassium was extracted by neutral $1 \mathrm{~N}$ ammonium acetate and it was estimated using flame photometer (Mohr et al., 1963).

\section{Results and Discussion}

\section{Nodulation Studies}

Response of the treatments (except $\mathrm{P}_{40}+\mathrm{UI}$, $\mathrm{UF}+\mathrm{LRh}, \mathrm{UF}+\mathrm{CRh}$ and $\mathrm{P}_{40}+\mathrm{CRh}$ ) varied significantly over the control of unfertilized + uninoculated (UFUI, table 1).The treatment $\mathrm{P}_{120}+$ LRhsignificantly increased the number of nodules plant ${ }^{-1}$ by 88.4 and $103.2 \%$ response, at 21 and 45DAS over the control (6.9 and 21.3 nodules plant ${ }^{-1}$, respectively). But the effect of $\mathrm{P}_{120}+\mathrm{LRh}$ was at par to that of $\mathrm{P}_{80}+\mathrm{LRh}$. Results proved that Rhizobium inoculation with increased phosphorus levels had positive effects on number of nodules plant $^{-1}$.

Fresh weight of nodules at 21 and 45 DAS among all the treatment combinations, $\mathrm{P}_{80}+\mathrm{LRh}$ responded the best by 84.4 and 93.7\%, over UFUI (103 and $240 \mathrm{mg}^{\text {plant }}{ }^{-1}$ ), respectively. But, the response from $\mathrm{P}_{80}+\mathrm{LRh}$ was at par to that from $\mathrm{P}_{120}+\mathrm{LRh}$. Dry weight of nodules at 21 DAS increase the dry weight of nodules with the treatment combination of $\mathrm{P}_{120}+\mathrm{LRh}$ by $69.2 \%$, over UFUI (65 mg plant ${ }^{-}$ ${ }^{1}$ ). However, the response of the treatment combination of $\mathrm{P}_{120}+\mathrm{LRh}$ was at par to that of $\mathrm{P}_{80}+\mathrm{LRh}$. While at $45 \mathrm{DAS}$ nodule dry weight 
the treatment combination of $\mathrm{P}_{120}+\mathrm{LRh}$ increased dry weight of nodules by $96.6 \%$, over UFUI (120 mg plant ${ }^{-1}$ ). However, the effect of $\mathrm{P}_{80}+\mathrm{LRh}$ was statistically at par to that of $\mathrm{P}_{120}+\mathrm{LRh}$.

$\mathrm{N}$ content of nodules at 21 and 45 DAS the treatment combination of $\mathrm{P}_{80}+\mathrm{LRh}$, among all, increased significantly the highest $\mathrm{N}$ content in nodules by 77.3 and $47.5 \%$, over UFUI $(2.03$ and $3.0 \% \mathrm{~N})$ respectively. But, the performance of $\mathrm{P}_{80}+\mathrm{LRh}$ was at par to that of $\mathrm{P}_{120}+\mathrm{LRh}$.

The positive results obtained might be due to are contributed by essential role of phosphorus in legumes which support early root formation and development of lateral, fibrous and healthy roots. Furthermore, phosphorus is an essential component in seed formation as it plays huge role in protein synthesis, phospholipids and phytin. These results are in agreement with the findings of (Son et al., 2007) where results showed that the application of bradyrhizobia (Bradyrhizobium japonicum) and phosphate solubilizing bacteria (Pseudomonas sp.) liquid inoculants on soybean seed before sowing plus $20 \mathrm{~kg}$ $\mathrm{N} / \mathrm{ha}$ enhanced the nodule number, fresh weight, dry weight of nodules.

Dhami and Prasad (2009) also reported that the increase in nitrogen content as well as number of nodules per plant due to the application of inoculation in combination with nitrogen and phosphorus fertilizer.

\section{pH and Organic Carbon}

Table-2 presents the data on soil $\mathrm{pH}$ and content of organic carbon in soil at harvest. Soil reactions (soil $\mathrm{pH}$ ) and organic carbon were statistically unaffected due to different levels of phosphorous and Rhizobium inoculation. However, maximum organic carbon was recorded by treatment $\mathrm{P}_{120}+\mathrm{LRh}$ $(0.58 \%)$. Gattani et al., (1976) reported that there was no noticeable change in soil $\mathrm{pH}$ due to continuous use of chemical fertilizer and biofertilizer.

Fig.1 Effect of liquid formulation and carrier based Rhizobium inoculants and different levels of phosphorus on soybean yields

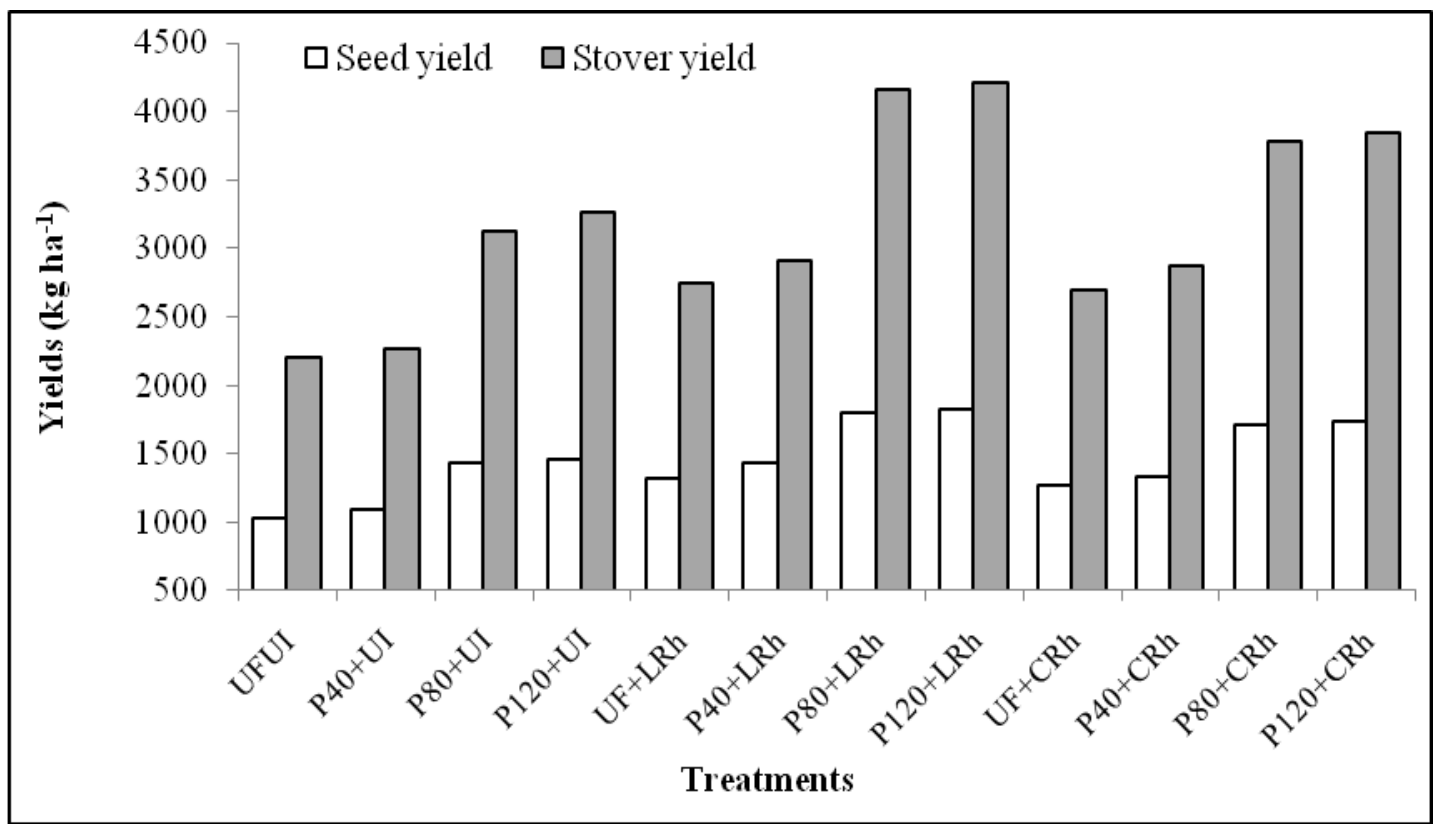


Table.1 Effect of liquid formulation and carrier based Rhizobium inoculants and different levels of phosphorus on nodulation attributes of soybean at different growth stages of crop

\begin{tabular}{|c|c|c|c|c|c|c|c|c|}
\hline \multirow[t]{2}{*}{ Treatments } & \multicolumn{4}{|c|}{21 DAS } & \multicolumn{4}{|c|}{45 DAS } \\
\hline & $\begin{array}{c}\text { Number / } \\
\text { plant }\end{array}$ & $\begin{array}{l}\text { Fresh wt. } \\
\text { (mg/ plant) }\end{array}$ & $\begin{array}{c}\text { Dry wt. } \\
\text { (mg/ plant) }\end{array}$ & $\begin{array}{c}\mathrm{N} \text { content } \\
(\%)\end{array}$ & $\begin{array}{c}\text { Number/ } \\
\text { plant }\end{array}$ & $\begin{array}{l}\text { Fresh wt. } \\
\text { (mg/ plant) }\end{array}$ & $\begin{array}{c}\text { Dry wt. } \\
\text { (mg/ plant) }\end{array}$ & $\begin{array}{c}\mathrm{N} \text { content } \\
(\%)\end{array}$ \\
\hline UFUI & 6.9 & 103 & 65 & 2.03 & 21.3 & 240 & 120 & 3.03 \\
\hline $\mathbf{P}_{40}+\mathrm{UI}$ & 6.9 & 93 & 67 & 2.13 & 23.5 & 260 & 130 & 3.06 \\
\hline $\mathrm{P}_{80}+\mathrm{UI}$ & 9.3 & 140 & 90 & 2.60 & 31.7 & 353 & 183 & 3.68 \\
\hline $\mathbf{P}_{120}+\mathrm{UI}$ & 9.7 & 127 & 84 & 2.77 & 33.8 & 357 & 187 & 3.75 \\
\hline $\mathrm{UF}+\mathrm{LRh}$ & 7.5 & 114 & 81 & 2.80 & 28.4 & 277 & 120 & 3.45 \\
\hline $\mathrm{P}_{40}+\mathrm{LRh}$ & 9.7 & 123 & 83 & 3.00 & 33.7 & 350 & 180 & 3.69 \\
\hline $\mathbf{P}_{80}+\mathrm{LRh}$ & 11.3 & 190 & 107 & 3.60 & 42.3 & 465 & 231 & 4.47 \\
\hline $\mathrm{P}_{120}+\mathrm{LRh}$ & 13.0 & 185 & 110 & 3.53 & 43.3 & 450 & 236 & 4.28 \\
\hline $\mathrm{UF}+\mathrm{CRh}$ & 8.1 & 107 & 75 & 2.70 & 26.7 & 260 & 153 & 3.35 \\
\hline $\mathbf{P}_{40}+\mathrm{CRh}$ & 8.2 & 111 & 80 & 2.90 & 31.6 & 283 & 157 & 3.45 \\
\hline $\mathbf{P}_{80}+\mathrm{CRh}$ & 10.8 & 147 & 93 & 3.43 & 36.8 & 387 & 207 & 4.23 \\
\hline $\mathrm{P}_{120}+\mathrm{CRh}$ & 11.0 & 143 & 98 & 3.30 & 40.6 & 373 & 200 & 4.20 \\
\hline $\mathrm{SE}_{\mathrm{m}} \pm$ & 0.80 & 11.05 & 5.88 & 0.17 & 2.83 & 29.88 & 14.07 & 0.22 \\
\hline $\mathrm{CD}_{5 \%}$ & 2.29 & 31.72 & 16.89 & 0.49 & 8.13 & 85.77 & 40.38 & 0.64 \\
\hline
\end{tabular}


Table.2 Effect of liquid and carrier based Rhizobium inoculants at different levels of phosphorus on soil $\mathrm{pH}$, organic carbon and available NPK in soil after harvest of crop

\begin{tabular}{|c|c|c|c|c|c|}
\hline \multirow[t]{2}{*}{ Treatments } & \multirow[t]{2}{*}{ pH } & \multirow[t]{2}{*}{$\mathrm{OC}(\%)$} & \multicolumn{3}{|c|}{ Available NPK $\left(\mathrm{kg} \mathrm{ha}^{-1}\right)$} \\
\hline & & & $\mathbf{N}$ & $\mathbf{P}$ & $\mathbf{K}$ \\
\hline UFUI & 7.42 & 0.52 & 189 & 14 & 236 \\
\hline $\mathbf{P}_{40}+\mathrm{UI}$ & 7.35 & 0.52 & 197 & 16 & 239 \\
\hline $\mathrm{P}_{80}+\mathrm{UI}$ & 7.31 & 0.53 & 235 & 21 & 243 \\
\hline $\mathrm{P}_{120}+\mathrm{UI}$ & 7.29 & 0.55 & 231 & 22 & 245 \\
\hline $\mathrm{UF}+\mathrm{LRh}$ & 7.34 & 0.54 & 224 & 18 & 263 \\
\hline $\mathrm{P}_{40}+\mathrm{LRh}$ & 7.30 & 0.55 & 237 & 22 & 264 \\
\hline $\mathrm{P}_{80}+\mathrm{LRh}$ & 7.26 & 0.57 & 278 & 27 & 295 \\
\hline $\mathbf{P}_{120}+\mathrm{LRh}$ & 7.14 & 0.58 & 270 & 29 & 286 \\
\hline $\mathrm{UF}+\mathrm{CRh}$ & 7.22 & 0.53 & 216 & 16 & 260 \\
\hline $\mathbf{P}_{40}+\mathrm{CRh}$ & 7.23 & 0.54 & 217 & 19 & 268 \\
\hline $\mathrm{P}_{80}+\mathrm{CRh}$ & 7.13 & 0.55 & 260 & 23 & 284 \\
\hline $\mathbf{P}_{120}+\mathrm{CRh}$ & 7.17 & 0.56 & 251 & 25 & 275 \\
\hline $\mathrm{SE}_{\mathrm{m}} \pm$ & 7.32 & 0.02 & 11.47 & 1.50 & 22.33 \\
\hline $\mathrm{CD}_{5 \%}$ & 0.20 & 0.06 & 32.94 & 4.30 & 64.11 \\
\hline
\end{tabular}

\section{Available N, P and $\mathbf{K}$}

The data regarding available $\mathrm{N}, \mathrm{P}$ and $\mathrm{K}$ content in soil $(0-15 \mathrm{~cm})$ after harvest of the crop are presented in table 2. Available $\mathrm{N}$ in soil varied from 189 to $278 \mathrm{~kg} \mathrm{~N} \mathrm{ha}^{-1}$. All the treatments (except $\mathrm{P}_{40}+\mathrm{CRh}, \mathrm{UF}+\mathrm{CRh}$ and $\left.\mathrm{P}_{40}+\mathrm{UI}\right)$ significantly increased the available $\mathrm{N}$ content in soil over the control UFUI plot. Among all the treatments, $\mathrm{P}_{80}+\mathrm{LRh}$ responded the best by $47.1 \%$ increase, followed by $\mathrm{P}_{120}+\mathrm{LRh}$ and $\mathrm{P}_{80}+\mathrm{CRh}$, by 42.9 and $37.6 \%$ increase, respectively over UFUI $(189 \mathrm{~kg} \mathrm{~N}$ $\left.\mathrm{ha}^{-1}\right)$. But, the performance of $\mathrm{P}_{80}+\mathrm{LRh}$ was at par to that of $\mathrm{P}_{120}+\mathrm{LRh}$.

Available $\mathrm{P}$ in soil varied from 14 to $29 \mathrm{~kg}$ ha 1. All the treatments (except $\mathrm{P}_{40}+\mathrm{CRh}$, $\mathrm{UF}+\mathrm{LRh}, \mathrm{UF}+\mathrm{CRh}$ and $\left.\mathrm{P}_{40}+\mathrm{UI}\right)$ performed significantly over the control. Among all the treatments, $\mathrm{P}_{120}+\mathrm{LRh}$ responded the best by $107.1 \%$ increase, followed by $\mathrm{P}_{80}+$ LRhand $\mathrm{P}_{120}+\mathrm{CRh}$, by 92.9 and $78.6 \%$ increase, respectively over the control $\left(14.0 \mathrm{~kg} \mathrm{P} \mathrm{ha}^{-1}\right)$. The response of $\mathrm{P}_{80}+\mathrm{LRh}$ was at par with
$\mathrm{P}_{120}+\mathrm{LRh}$. The data on available $\mathrm{K}$ in soil varied from 236 to $295 \mathrm{~kg} \mathrm{ha}^{-1}$. All the treatments varied numerically but nonsignificantly over the control of UFUI. Among all the treatments, $\mathrm{P}_{80}+\mathrm{LRh}$ responded the best by $25.0 \%$ increase and this was followed by $\mathrm{P}_{120}+\mathrm{LRh}$ over the control of UFUI.

However, the performance of $\mathrm{P}_{80}+\mathrm{LRh}$ was at par to that of $\mathrm{P}_{120}+\mathrm{LRh}$.Pandey et al., (2015) also reported that combined inoculation of Rhizobium, PSB and PGRR improved the nutrient status of soil through their synergistic effect on nitrogen fixation and solubilisation of native soil phosphorus which increased availability and uptake of these nutrients by the crop plant (Urd bean) resulted in enhanced yield indices. Higher NPK uptake in combined inoculation of Rhizobium + PSB + PGRR is due to their additive effects (Prasad et al., 2002). Seed inoculation with biofertilizers reduced the bulk density and enhanced organic carbon and available $\mathrm{N}, \mathrm{P}$ and $\mathrm{K}$ contents of the soil. 


\section{Crop Yields}

The effects of liquid and carrier based Rhizobium inoculants supplemented with different levels of Phadbeneficial effect on seed and Stover yields of soybean over the UFUI (Fig.1).The maximum seed yield was recorded with $\mathrm{P}_{120}+\mathrm{LRh}$ and $\mathrm{P}_{80}+\mathrm{LRh}$ which increased the seed yield by 78.5 and $75.4 \%$, respectively over the control $\left(1025 \mathrm{~kg} \mathrm{ha}^{-1}\right)$. But, the results were mutually at par. Likewise, with $\mathrm{P}_{120}+\mathrm{CRh}$ and $\mathrm{P}_{120}+\mathrm{CRh}$ the increase was 69.0 and $66.9 \%$ increase, respectively. The relatively better response was recorded from the treatment of $\mathrm{P}_{80}+\mathrm{LRh}$ by $5.1 \%$ over $\mathrm{P}_{80}+\mathrm{CRh}\left(1711 \mathrm{~kg} \mathrm{ha}^{-1}\right)$. Similar to seed yield, the higher Stover yield was recorded with $\mathrm{P}_{120}+\mathrm{LRh}$ and $\mathrm{P}_{80}+\mathrm{LRh}$ which increased the yield by 91.0and $88.8 \%$, respectively over the control $\left(2206 \mathrm{~kg} \mathrm{ha}^{-1}\right)$ and the respective results were mutually at par. Similar was the case with $\mathrm{P}_{120}+\mathrm{CRh}$ and $\mathrm{P}_{120}+\mathrm{CRh}$ (by 74.0 and $71.1 \%$ increase, respectively) over the control. The relative performance of $\mathrm{P}_{80}+\mathrm{LRh}$ was $10.3 \%$ more over $\mathrm{P}_{80}+\mathrm{CRh}\left(3775 \mathrm{~kg} \mathrm{ha}^{-1}\right)$.Increase in yields with liquid inoculums of Rhizobium with inorganic $\mathrm{P}$ fertilizer might be attributed to better nodulation, $\mathrm{N}_{2}$ fixation and crop growth as against uninoculated control (Brahmaprakash et al., 2004 and Gupta, 2005). In the basis of findings it may be concluded that the inoculation with Rhizobium cultures strains and phosphorus supply improved productivity of soybean. The use of these effective strains of Rhizobium and phosphorus supplementation could be an effective way to enhance thenodulation attributes, available soil N, P and $\mathrm{K}$ in soil and as well as yield of soybean.

\section{References}

Akpalu, M. M., Siewobr, H., Oppong-Sekyere, D. and Akpalu, S. E. 2014. Phosphorus application and Rhizobia inoculation on growth and yield of soybean (Glycine max L. Merrill).Am. J. Exp. Agr. 4(6): 674-685.

Amma, M. K. 1989. Plant and soil analysis. Rubber res. ins. Rubber Board, Kottayam Kerala.

Brahmaprakash, G. P., Girisha, H. C., NaviVithal and Hedge, S. V. 2004. Biological nitrogen fixation in pulse crops. Pulses in New Perspective (Masood Ali, B.B Singh, Shiv Kumar and Vishwa Dhar, eds.), Indian Society of Pulses Research and Development, IIPR, Kanpur, India. 271286.

Dhami N. and Prasad, B. N. 2009. Increase in root nodulation and crop yield of soybean by native Bradyrhizobium japonicumstrains. Botanica Orientalis-Journal of Plant Science. 6: 1-3.

Gattani, P. D., Jain, S. V., Seth, S. P. 1976. Effect of continuous use of chemical fertilizer and manures on soil physical and chemical properties. J. Indian Society Soil Science. 24: 284-289.

Gupta, S. C. 2005. Evaluation of liquid and carrier based Rhizobium inoculants in chickpea. Indian Journal Pulses Research. 18(1): 4042.

Hungria, M. R. J., Campo, I. C. Mendes and Graham, P. H. 2006. Contribution of biological nitrogen fixation to the $\mathrm{N}$ nutrition of grain crops in the tropics: the success of soybean (Glycine $\max$ L. Merr.) in South America. In: Nitrogen nutrition and sustainable plant productivity. (Eds) Singh R.P., N. Shankar and P.K. Jaiwa. Stadium Press, Houston. 43-93.

Kwarteng, J. A., Towler and M. J. 1994. West Africa Agriculture. A textbook for schools and colleges, by Macmillan Publication Press Limited, p. 144-116.

Makoi, J. H. J., Bambara, R. S. and Ndakidemi, P. A.2013. Rhizobium Inoculation and the Supply of Molybdenum and Lime Affect the Uptake of Macronutrients in Common Bean (P. vulgaris L.). Plants. Aust. J. Crop Sci. 7(6): 784-793.

Miller, R. H., and Keeney, D. R. 1982. Estimation of available phosphorus in soil by extraction with sodium bicarbonate. Circ. U.S Department Agriculture. 939: 1-20. 
Mohr, G. R., Daija, N. P., Subbaramany, H. S., Leleyand, V. K. and Danalrue, R.L. 1963. Soil testing in India Asian Press, New Delhi.

O'Hara, G., Yates, R. and Howieson, J. 2002. Selection of strains of root nodule bacteria to improve inoculant performance and increase legume productivity in stress full environments. In: Herridge D (eds) Inoculants and Nitrogen fixation of legumes in Vietnam. ACIAR Proceedings. 109: p. 75-80.

Olsen, S. R., Cole, C. V., Vatanabe, F. S. and Dean, L. A. 1954. Estimation of available phosphorus in soil by extraction with sodium bicarbonate. Circ. U.S. Department. Agriculture. 939: 1-19.

Pandey, I.B., Pandey, R. K. and Kumar, R. 2015. Integrated nutrient management for enhancing productivity and profitability of long duration pigeon-pea (Cajanus cajan) under rainfed condition. India nJ. Agron. 60(3): 436-442.

Piper, C. S. 1950.Soil and Plant Analysis. Intel Science Publishers. Inc. New York.

Plaxton, W. C. 2004. Plant response to stress: biochemical adaptations to phosphate deficiency. In: Goodman R (eds) Encyclopedia of Plant and Crop Science. Marcel Dekker, New York. p. 976-980.

Prasad, H., Chandra, R., Pareek, R.P. and Kumar, N. 2002. Synergism among phosphate solubilizing bacteria, rhizo bacteria and Rhizobium with urdbean. Indian J. Pulse Res., 15(2): 131-135.

Ruhul, A. A. K. M., Jahan, S. R. A., Karim, M. F., Hasanuzzaman, M. 2009. Growth dynamics of soybean (Glycine max L.) as affected by varieties and timing of irrigation. American Eurasian J of Agronomy. 2: 95-103.

Scherer, H.W., Pacyna, S. Spoth, K. R. and Schulz, M. 2008. Low levels of ferredoxin,
ATP and leghemoglobin contribute to limited $\mathrm{N}_{2}$ fixation of peas (Pisum sativum L.) and alfalfa (Medicago sativa $\mathrm{L}$.) under $\mathrm{S}$ deficiency conditions. Biol. Fert. Soils.44: 909-916.

Simmonds, N. W., Smartt, J., Millen, S. and Spoor, W. 1999. Principles of crop improvement, $2^{\text {nd }}$ edition. Published Longman Group Ltd. p 252-256.

Smaling, E. M. A, Roscoe, R., Lesschen, J. P., Bouwman, A. F. and Comunello, F. 2008. From forest to waste: Assessment of the Brazilian soybean chain, using nitrogen as a marker, Agric. Ecosyst. Environ. 128: 185197.

Son, T. T. N., Diep, C. N., Giang, T. T. M. and Thu, T. T. A. 2007. Effect of co-inoculants (Bradyrhizobia and Phosphate solublizing Bacteria) Liquid on soybean under rice based cropping system in the Mekong delta. Omonrice 15: 135-143.

Subbiah, B. V. and Asija, E.C. 1956. A rapid procedure for estimation of available nitrogen in soil. Current Sciences25: 259260.

Subbiah, B.V., and Asija, E.C. 1956. A rapid procedure for estimation of available nitrogen in soil. Current Sciences.25: 259260.

Tairo, E. V. and Ndakidemi, P.A. 2014. Macronutrients uptake in soybean as affected by Bradyrhizobium japonicum inoculation and phosphorus supplements. Am. J. Plant Science.5: 488496.

Walkley, A. and I. A. Black. 1934. An examination of Degtjareff method for determining soil organic matter and a proposed modification of the chromic acid titration method. Soil Sci. 37: 29-37.

\section{How to cite this article:}

Shish Ram Jakhar, Vinod Kumar, N. G. Mitra and Ompal Singh. 2018. Effect of Soybean (Glycine max) Seed Inoculation with Liquid and Carrier Based Rhizobium cultures and Phosphorus Levels on Productivity and Physico-Chemical Properties of Soil. Int.J.Curr.Microbiol.App.Sci. 7(06): 1807-1814. doi: https://doi.org/10.20546/ijcmas.2018.706.215 